their consequences, of sustainable development, the ALARA ("as low as reasonably achievable") principle, and the principles of protection of future generations and of good neighbourliness are all mentioned in the text.

All these elements make this Convention an important step in the field of international nuclear law.

Amelia de Kageneck and Cyrul Pinel*

\title{
ARE JUDGES BEYOND CRITICISM UNDER ARTICLE 10 OF THE EUROPEAN CONVENTION ON HUMAN RIGHTS?
}

\section{A. Introduction}

On the premise that democratic government is founded, inter alia, on the accountability of public bodies and their officials, as well as on the popular participation in collective decision-making by the governed at all levels of government, there is merit in the proposition that it is improper to curb open debate, especially in matters which are of public interest. In so far as the work of the judiciary in general, and of judges in particular, is in the public domain and thus of public interest, the value of the freedom of expression applies, in principle, with equal force. Freedom of expression in the legal domain and in relation to the work of judges serves a variety of useful purposes in democratic society. Freedom of expression serves to uphold the integrity of the principles of democracy which require that governmental institutions should be transparent and accountable, and in that sense the judicial domain, very much like other branches of government, benefits from a healthy exchange and interaction of opinions. The administration of justice is better served by well-informed participants than by ignorance, and freedom of expression can contribute to a full and rigorous assessment of information in the judicial context. Similarly, in modern democratic society, all individuals, but especially legal journalists, lawyers and other officials of the legal establishment, contribute to the architecture of judicial policy through the expression of their opinions. Freedom of expression in this context can also prove to be an instrument of individual and professional self-fulfilment. This is considered crucial in any society which is dependent upon the participation of the people.'

The European Court of Human Rights (the Court) ${ }^{2}$ has endorsed the import-

* Both authors have attended the meetings of the Group of Legal and Technical Experts in charge of drafting the Joint Convention. Amelia de Kageneck represented the OECD Nuclear Energy Agency as an observer and Cyril Pinel was a member of the French delegation. Amelia de Kagenect worts with the Legal Affairs Section of the OECD Nuclear Energy Agency. Cyril Pinel works in the International Relations Directorate of the French Commissariat à l'Energie Atomique. The opinions expressed by the authors are not necessarily those of their respective organisations.

1. For the place of these values in a democratic society see Barend van Niekerk. The Cloistered Virtue. Freedom of Expression and the Administration of Justice in the Western World (1987), chap.1. On the general principles relating to the value of freedom of expression see Eric Barendt, Freedom of Speech (1987) and Frederick Schauer, Free Speech. A Philosophical Enquiry (1982).

2. The supervision of contracting States' compliance with the Convention is presently undertaken by the European Commission of Human Rights (Arts.19-37 of the Convention), 
ance of this principle of open debate and the unrestrained exchange of views on matters of public interest ${ }^{3}$ in its decisions relating to Article 10 of the European Convention on Human Rights (the Convention), ${ }^{4}$ which guarantees freedom of expression. The Court has been particularly unyielding in upholding this freedom. The Court has rejected various attempts to justify restrictions on critical comment about public officials ${ }^{5}$ other than judges. Concerning judges, there is evidence to suggest that the Court is unwilling to apply the same rigorous standard of supervision. The Court's approach to the criticism of judges is not entirely dissimilar to the description adopted by one English lawyer of the popular attitude to the criticism of English judges: ${ }^{6}$

Laymen treat judges as a priestly caste to whoin they are reluctant to apply the standards of criticism imposed on other public servants. Lawyers tend to be conservative in their attitudes in this as in other respects. The iron of the doctrine of precedent has entered into their souls. If they do have suggestions for reform of the judiciary, or comments to make on judicial performance, they whisper them to each other over lunch in the Middle Temple or in professional journals remote from the public gaze. Such heresies are expressed cautiously, in deferential language.

This article, which assesses the standard of supervision relating to the criticism of judges, argues that the relative differences in the Court's case law relating to judges are not inconsistent with the policy of upholding democratic ideals which underlies the interpretation of Article 10, although if the changing attitudes to the criticism of judges currently taking hold in the case law of some countries were to become widespread, the Court could well have to reconsider its present position.

\section{B. Criticising Judges}

Although the drafters of the Convention anticipated the permissibility of limitations on freedom of expression in order to uphold the authority and impartiality of the judiciary, the scope of these principles in the practical context of criticising

the European Court of Human Rights (Arts.38-56) and the Committee of Ministers (Arts.31, 32 and 54), although in practice the Court's responsibilities are the most important (see Art.45). In any case, with the recent adoption of Protocol No.11 to the Convention (text reprinted in (1994) 15 Human Rights $L J .86$ ) the Court and the Commission are expected to be merged into a single court with the coming into force of the Protocol. On Protocol No.11 see A. Drzemezweshi and J. Meyer-Ladewig, "Principal Characteristics of the New ECHR Control Mechanism as Established by Protocol 11, Signed on 11 May 1994" (1994) 15 Human Rights LJ. 81; H. G. Schermers, "The Eleventh Protocol to the European Convention on Human Rights" (1994) 19 E.L.Rev. 367; A. R. Mowbray, "A New European Court of Human Rights" (1994) Public Law 540.

3. Handyside v. United Kingdom, Eur.Ct.H.R, Ser.A.24 (1976), 1 E.H.R.R. 737; Sunday Times v. United Kingdom (No.1), Eur.Ct.H.R. Ser.A.30 (1979), 2 E.H.R.R. 245; Lingens v. Austria, Eur.C.H.R., Ser.A.103 (1986), 8 E.H.R.R. 103; Oberschlick v. Austria, Eur.C.H.R, Ser.A.204 (1991); 19 E.H.R.R. 389.

4. Convention for the Protection of Human Rights and Fundamental Freedoms (Rome 1950), text reprinted in Browntie, Basic Documents on Human Rights (1992), p.326.

5. See Lingens v. Austria, supra n.3, Schwabe v. Austria, Eur.Ct.H.R., Ser.A.242-B (1993) (politicians); Thorgeir Thorgeirson v. Iceland, Eur.Ct.H.R, Ser.A.239 (1992), (1994) 18 E.H.R.R. 843 (police); Castells v. Spain, Eur.Ct.H.R, Ser.A.236 (1992), 14 E.H.R.R. 445 (government policy).

6. David Pannick, Judges (1987), p.105. 
judges could not have been anticipated. It is clear from the Barford v. Denmark? and Prager and Oberschlick v. Austrias cases that where judges are the target of critical comment the Court applies its principles for interpreting Article 10 rather differently. Because of the wider margin of appreciation granted to the contracting States, the scope and effect of the permissible limitations are also wider in those instances involving the criticism of judges than in the majority of instances where other public officials are the subject of critical comment. The Court's traditional bias in favour of the first paragraph of Article 10 is evidently reversed in favour of the second paragraph in cases involving the criticism of judges, prompting the question at this point whether such a reversal of approach is in itself an irreconcilable contradiction in the Court's policy. That there are differences in the application of principles does not necessarily amount to such a contradiction as long as the Court aims to uphold the ideals of democratic society relating to freedom of expression. It is true that these ideals may require different approaches when the facts, contexts and circumstances are different. This conclusion follows the principles of treaty interpretation set out in Article 31 of the Vienna Convention on the Law of Treaties.' The requirement in that provision to take account of the context as well as the object and purpose of treaty terms allows tribunals to arrive at different conclusions in cases which may possess common elements-in this case the scope of freedom of expression in relation to a particular kind of public official.

The Court has expressly highlighted differences in the application of its principles of interpretation between the criticism of politicians on the one hand and the criticism of governments on the other, pointing out that the limits of permissible criticism are higher with regard to the latter.$^{10}$ Similar distinctions have been drawn between the criticism of public officials and private individuals in the Lingens v. Austria and Thorgeir Thorgeirson v. Iceland cases. ${ }^{11}$ There are conceivably other differences of general characterisation such as between political expression, commercial speech and civil expression under Article 10 which may necessitate alterations in the application of the general principles. In Barford v. Denmark the Court insisted on a higher standard of proof because in the opinion of the Court the criticisms were of the lay judges personally, ${ }^{12}$ presupposing that a different, perhaps lesser standard of proof would have been enough if the criticism related to them in their official capacity. While a distinction between the personal and the public sides of judicial responsibility may be difficult to draw in practice, the point is here well made that the ideals of democratic society necessitate a different approach to the criticism of judges, and in this sense the Court has been remarkably consistent. Furthermore, the judges in Barford were not professional judges.

7. Eur.C.H.R., Ser.A.149 (1989), (1991) 13 E.H.R.R. 493.

8. Eur.C.H.R., Ser.A.313 (1994), (1996) 21 E.H.R.R. 1.

9. Art 31 of the Vienna Convention on the Law of Treaties provides, inter alia. "A treaty shall be interpreted in good faith in accordance with the ordinary meaning to be given to the terms of the treaty in their context and in the light of its object and purpose." For text see (1969) 8 I.L.M. 679 and I. Brownlie, Basic Documents in Intemational Law (1995), p.388.

10. Castells v. Spain, supra n.S, at para.46.

11. Supre nn.3,5.

12. Barford v. Denmark, supra n.7, at para.33, for a contra conclusion see the dissenting opinion of Judge Golcuklu, idem, pp.501-502. 
They were ordinary members of the public who were required by law to undertake duties that one would normally expect to be performed by professionals. They were, in reality, not acting in a professional capacity as public servants and in that sense the limits of criticism would be expected to be narrower. In his strong dissenting opinion to the Prager and Oberschlick judgment, Judge Martens endorsed the principle of treating different forms and targets of criticisms differently as long as the scrutiny remained consistently rigorous. Viewing the Court's decisions relating to the criticism of judges as belonging to a separate category of cases to which the general principles apply differently, it is beyond doubt that the Court's conclusions were correct. ${ }^{13}$ No doubt it would have been preferred for the Court to be much more open and precise about its reasons rather than leaving it to commentators to speculate on them.

Other authors have sought to explain the Court's decisions with regard to the criticism of judges rather differently. Colin Warbrick, for instance, in his review of Barford identifies some of these explanations, including the following: ${ }^{14}$

First, there is that judicial freemasonry which seems to make judges particularly sensitive to the slights aimed at their brethren. Next and closely associated with it, is the notion that judges cannot protect themselves, that the requirements of their office forbid their engaging in controversy, particularly in matters in which they have been involved. More fundamentally, it is an implied affirmation of the subsidiary role of the Convention to protecting rights. There is no consistency in this but the reluctance of the Court to substitute its judgment for the considered opinion of a national decisionmaker (particularly a national court) is marked. A minimum standard is preserved.

There may be evidence to support some of these explanations but others may turn out to be harsh or unfounded. ${ }^{\text {s }}$ The conspiracy theory explanation in the nature of judicial freemasonry is one of the explanations for which there is no verifiable evidence. Judges, being human, may very well be occasionally inclined to cover up misbehaviour within their ranks, but they are professionals also. Their training, selection and experience should be sufficiently rigorous to enable them to overcome such shortcomings. It is also important to note that in the context of the European Court of Human Rights, the judges are drawn from the best in the member States and, above all else, because their tenure and salaries are paid by the Council of Europe, they are isolated from the politics of member States. It will be

13. For a contrary view see Anthony Lester, "Freedom of Expression", in R. St J. Macdonald, Matscher and Petzold, The European System for the Protection of Human Rights (1993), pp.465, 477. The general conclusions of other writers on similar issues would seem to support Lord Lester's conchusions. See e.g. Clive Walker, "Scandalising in the Eighties" (1985) 101 L.Q.R. 359, 382, where he argues that the offence of scandalising a court or judge (an offence that could arise from criticising a court or judge under English law) might be contrary to Art.10(1) of the European Convention on Human Rights and abo Pannick, op. cit. supra n.6, at p.115, who argues that "the offence of scandalising the judiciary does survive as an unjustifiable impediment to the freedom of speech about the judiciary". 445 .

14. Colin Warbrict, "The European Convention on Human Rights" (1989) 9 Y.E.L 439.

15. E.g. on the subject of judges' inability to reply to criticism see Lord Denning in $R$ v. Commissioner of Police of the Metropolis, ex p. Blackbum (No.2) [1968] 2Q.B. 150, 155; see also Report of the Committee on Contempt of Court (Phillimore Committee Report) Cmnd 5794 (1974), para.162. For a contrary view, however, see Pannick, op. cit. supra n.6, at pp.128-133, 177-179; and Walker, op. cil supra n.13, esp. at pp.379-380. 
difficult successfully to canvass support within their ranks for any decision which is based on dishonesty and corruption within the judiciary of a contracting State.

The other explanations may have substance mainly because of the special characteristics of the judicial branch of government. That branch and the judges who are part of it must be treated differently from the other branches, especially the executive branch. Judges have to be independent and yet conceptually they are a part of the government with responsibilities to control all forms of official excesses. In any society governed by law, where this makes the maintenance of public confidence in the judiciary indispensable, harsh criticism which questions the integrity of judges also questions their independence and if it is unfounded can be damaging to the democratic process. In these circumstances one must admit that it is not ideal that judicial self-discipline is the only practical means of calling this branch of government to account, making the judicial branch the inevitable weak link in the effort to attain the ideals of democratic society. This fact though should not cause undue concern unless there is evidence of abuse and exploitation of this weakness in practice. This risk has been a part of democratic political theory of the founding States of the Council of Europe. All member States today ascribe to the original ideals, with their shortcomings, including the extra protection for the judicial branch. In the United Kingdom, for example, the law of contempt of court, ${ }^{16}$ both in the face of and out of the court, under which nothing is allowed to be done which undermines public confidence in the court, scandalises the court or threatens the independence of the judiciary, is an example of the special protection laid down for the judicial branch. ${ }^{17}$ Similar protection exists in the laws of other countries and this has always been a factor to be balanced against the individual's freedoms guaranteed in the domestic context. ${ }^{18}$ In most of the countries of the Council of Europe there are a variety of formal as well as informal mechanisms for restricting or penalising criticism of judges. Countries such as France, Netherlands, Spain, Italy, Sweden, Norway and of course Denmark (the country from which Barford originated) have widely drafted provisions in their penal codes which may be interpreted to make it an offence to criticise judges. ${ }^{19}$ There are other countries, such as Germany, Switzerland and Austria (whence Prager and Oberschlick originated), where the laws on civil and criminal defamation are open to judges and private citizens in exactly the same way. ${ }^{20}$ Treating judges as private citizens under the ordinary laws of defamation makes the necessity of a higher

16. See Sunday Times (No.1), supra n.3, at para.60.

17. In R. v. Gray [1900]2 Q.B. 36, 40, Lord Russell of Killowen defined contempt of court: "Any act done or writing published calculated to bring a Court or a judge of the Court into contempt, or to lower his authority, is a contempt of court." See generally on this subject Phillimore Report, supro n.15, esp. at chaps.1 and 7, and G. Borrie and N. Lowe, The Law of Contempt (1973), esp. chap.6. See also the UK Contempt of Court Act 1981. For a discussion of the effect of the 1981 Act on the subject of scandalising the judiciary see Walker, op. cit supra n.13.

18. For a review of cases in this field in other, mostly common law Commonwealth jurisdictions see Geoffrey Robertson and Andrew Nicol, Media Law (1992), pp.296-299. In other, mostly Continental European countries the protection of judges is usually incorporated in their Civil and Criminal Codes. See also Walker, ibid.

19. For a review of the provisions of the relevant Penal Codes in these countries see van Niekerk, op. cit supro n.1, at chap.2.

20. lbid. 
standard of proof inevitable. Such an approach may have had an influence on the reasoning of the European Court of Human Rights. In some other countries, such as Germany, some of the restraints on judicial criticisms are imposed by principles of professional ethics, ${ }^{27}$ while in other countries, including the Netherlands and Switzerland, some of the inhibitions are driven by cultural attitudes. ${ }^{2}$ In Switzerland, for instance, it has been argued that the decentralisation of judicial responsibilities between the federal government and the cantons has created "a close interaction between local communities (which, for the most part, are extremely conservative according to Western European standards) and the legal profession, a situation that results in a much greater degree of cozy conformism and a lack of critical scrutiny of the administration of justicen. ${ }^{20}$

In effect, it is possible to conclude that, on the matter of criticising judges, there is a consistent and firmly established practice (albeit of different approaches) not to tolerate it, especially if such criticism is immoderate. On this basis, and also in the light of the principle of subsidiarity in relation to the version of democracy which guides the interpretation of the Convention, it certainly would have been unusual for the Court of Human Rights to seek radically to amend this relationship without compelling reasons. The suggestion that the Court is reluctant to substitute its judgment for the considered opinion of a national court is correct in this context, especially on an issue such as the protection of the judiciary, upon which there is a fair amount of consensus in the various legal systems under the Convention. The practice of protecting judges from abuse is so well grounded in the theory and practice of Western liberal democracy that it can be altered only by the contracting States themselves.

In mirroring the practice in member States the Court's conclusions on the criticism of judges amount, in effect, to the imposition of prior restraints on freedom of expression in this field. In principle, prior restraints can undermine the purposes of freedom of expression in a democratic society and should be used restrictively. ${ }^{24}$ In relation to the press, for instance, prior restraints can create a "chilling" effect in the performance of their duties as public watchdog. The European Court of Human Rights generally recognises the damaging effect of prior restraints ${ }^{3}$ but wishes to distinguish their impact in the special circumstances involving the criti-

\section{Ibid.}

22. lbid

23. Idem, p.90.

24. The US Supreme Court has held prior restraints on freedom of speech to be unconstitutional and thus illegal: see New York Times Co. v. United States 403 U.S. 713 (1971).

25. In Goodwin v. Uniced Kingdom (1996) 22 E.H.R.R. 123, involving the disclosure of journalistic sources, the Court said (at para.29): “Protection of journalistic sources is one of the basic conditions for press freedom, as is reflected in the laws and the professional codes of conduct in a number of Contracting States and is affirmed in several international instruments on journalistic freedoms. Without such protection, sources may be deterred from assisting the press in informing the public on matters of public interest. As a result the vital public-watchdog role of the press may be undermined and the ability of the press to provide accurate and reliable information may be adversely affected. Having regard to the importance of the protection of journalistic sources for press freedom in a democratic society and the potentially chilling effect an order of source disclosure has on the exercise of that freedom, such a measure cannot be compatible with Article 10 of the Convention unless it is justifled by an overriding requirement of public interest." 
cism of judges. In other words, the Court recognises, in cases involving the criticism of judges, a real danger of undermining the democratic principles within which member States operate. As indicated, it is an imperfect form of democracy which on occasions such as those discussed here can accommodate deviations from the ideal norms.

\section{Impartiality of tribunal}

There is another important dimension of the freedom of expression debate in the present context. This relates to the question of how much weight, and if so in which direction, should be attached to the fact that, when individuals are charged with offences relating to the criticism of judges, the matter is adjudicated upon by the alleged victim's colleagues. In the special protection for the judicial branch of government through the law of contempt or other similar offences, courts are called upon to perform an impossible task of upholding the democratic process by ironically being judges in their own cause. The simple and perhaps unequivocal fact that by the nature of their professional training judges should be able to isolate most if not all of their prejudices does not necessarily address the perceptions from the external outlook that the case is somehow tainted with some degree of impartiality. Should the domestic and international courts, in recognition of this fact, be prepared to lend greater weight to the freedom of expression principle in this context? Although this issue was not argued before the domestic courts or the European Court, it deserves to be highlighted because of its potential impact on the quality of the judgments in this type of case. There is a specific requirement in Article 6(1) of the Convention for an impartial tribunal in the determination of civil rights or criminal charges. This has been interpreted to involve two tests-a subjective test and an objective test. According to the Court of Human Rights:26

The existence of impartiality for the purpose of Article 6(1) must be determined according to a subjective test, that is on the bias of the personal conviction of a particular judge in a given case, and also according to an objective test, that is ascertaining whether the judge offered guarantees sufficient to exclude any legitimate doubt in this respect.

It is the latter-objective-impartiality, which is usually based on appearances" 7 rather than on empirical fact, which is at issue in the present context. This notion of objective impartiality is the equivalent of the requirement in most common law jurisdictions that justice must not only be done but must also be seen to be done. Both Barford and Prager and Oberschlick can be said to have impacted on this matter of objective impartiality, which under normal circumstances could lead to the setting aside of domestic court decisions by the European Court. The factor of inevitability - that is to say, judges alone under the system of government have this responsibility for adjudicating disputes of this nature-makes it impossible to remove the cases involving criticism of their colleagues from their jurisdiction. The issue of potential bias in the objective sense will have to remain unresolved.

26. Hauschildt v. Denmark Eur.C.H.R., Ser.A.154 (1989), para.46; (1990) 12 E.H.R.R. 266, para.46.

27. Sramek v. Austria, Eur.Cl.H.R., Ser.A.84 (1984), para.42; (1985) 7 E.H.R.R. 351, para.42. 
It is possible, however, to assess this same matter from a completely different angle: that of competing rights claims involving the freedom of expression on the one hand and maintaining confidence in the judicial process on the other. ${ }^{2} \mathrm{Judges}$ are expected to strike a balance which upholds the democratic process. It is clear from this balancing process that the criticism of judges and their work as such is not prohibited and, as one English judge succinctly put it:20

The path of criticism is a public way: the wrong headed are permitted to err therein: provided that members of the public abstain from imputing improper motives to those taking part in the administration of justice, and are genuinely exercising a right of criticism, and are not acting in malice or attempting to impair the administration of justice, they are immune. Justice is not a cloistered virtue: she must be allowed to suffer the scrutiny and respectful, even though outspoken, comments of ordinary men.

Legitimate criticism must, however, be distinguished from "personal, scurrilous abuse of a judge ${ }^{n} .{ }^{30} \mathrm{In}$ an attitude not entirely dissimilar to that adopted by the European Court of Human Rights in Prager and Oberschlick, the practice in most domestic courts is to accept temperate, reasoned and fair criticism. ${ }^{31}$ Thus, according to Lord Salmon in R. v. Metropolitan Police Commissioner, ex parte Blackbum (No.2), "it follows that no criticism, however rigorous, can amount to contempt of court, provided it keeps within the limits of reasonable courtesy and good faith"." In Prager and Oberschlick, for instance, the domestic Austrian courts and the European Court were persuaded by the immoderate nature of the language used. It was also felt that such language was unnecessary and rather disproportionate in view of the fact that there was no overwhelming evidence from the article that obvious injustices had been done as a consequence of the judges' behaviour. In these circumstance the criticisms seemed more gratuitous value judgments and less of a fair comment. Such a conclusion allows any court to attach less weight to the freedom of expression claim.

\section{Progressive Trends}

In English law, as in other jurisdictions such as Canada, there is a growing feeling that the special and extra protection for the judiciary does not need strict enforce-

28. A similar sentiment was expressed by Mr Justice Black in the majority opinion in Bridges v. Califormia 314 U.S. 252, 260 (1941) where he indicated that "free speech and fair trials are two of the most cherished policies of our civilisation, and it would be trying to choose between them".

29. Per Lord Atkin in Ambard v. Attomey-General of Trinidad and Tobago [1936] A.C. 322, 335.

30. Per Lord Russell of Killowen CJ in R. v. Gray [1900] 2 Q.B. 36, 40-in dealing with a newspaper article which described a judge as an "impudent little man in horse hair, a microcosm of conceit and empty headedness".

31. See R. v. Westem Printing and Publishing Limited (1954) III C.C.C. 122 (Newfoundland Sup.Ct.), referred to in Borrie and Lowe, op. cit. supra n.17, at pp.163-164; $R$. v. Wiseman [1969] N.Z.L.R. 55; $R$. v. Gray, ibid, where Lord Russell pointed out that "judges and courts are alike open to criticism, and if reasonable argument or expostulation is offered against any judicial act as contrary to law or the public good, no court could or would treat that as contempt of court". See also R. v. Fletcher, ex p. Kisch (1935) S2 C.L.R. 248 and Attomey-General v. Butler [1953] N.Z.L.R. 944.

32. [1968] 2 Q.B. 150, 155. 
ment in order to uphold the democratic ideals. The English judge Lord Diplock, for instance, recently indicated that contempt of court arising from scandalising the judiciary has become "virtually obsolescent in the United Kingdom", before then another English judge had expressed the view that citation and prosecution for contempt arising from critical comments about the judiciary and their work were not at all worthwhile. ${ }^{34}$ It is equally noteworthy of this changing trend that in the heat of the infamous Spycatcher ${ }^{3 s}$ litigation (1987) in the United Kingdom the Daily Mirror newspaper was not prosecuted for contempt when it published upside-down photographs of the members of the House of Lords who had granted an injunction prohibiting publications about the book, under the headline "YOU FOOLS".\$ In fact, the number of prosecutions for this sort of contempt in the United Kingdom has reduced considerably" ${ }^{3}$ and there has not been a successful prosecution for over half a century."

It was the conventional wisdom in the United Kingdom until recently that judges had to be insulated from the controversies and thus criticisms of the day. This was publicly expressed in terms of the fact that judges were vulnerable in so far as they were not able to reply to criticisms. In reality the truth lay in what have come to be known as the "Kilmuir Rules", by the terms of which no judge was allowed to speak publicly without the prior approval of the Lord Chancellor's office. When Lord Kilmuir wrote the so-called Kilmuir Rules in a letter to the Director-General of the BBC in 1955, he was far more transparent about the reason for keeping judges' protection. He reasoned that: "So long as a judge keeps silent his reputation for wisdom and impartiality remains unassailable; but every utterance which he makes in public, except in the actual performance of his judicial duties, must necessarily bring him within the focus of criticism. ${ }^{n 99}$ The present Lord Chancellor, Lord Mackay of Clashfern, came to the conclusion that the façade sought to be built around judges was incompatible with the independence of the judiciary and so he abolished the Kilmuir Rules. ${ }^{* 0}$ Today, the atmosphere in which judges operate is far more liberat ${ }^{41}$ and judges take and, when appropriate,

33. Secretary of State for Defence v. Guardian Newspapers Limited [1985] A.C. 339, 347.

34. Per Lord Hailsham in Badry v. DPP of Mauritius [1982] 3 All E.R. 973. In that case Commonwealth countries were urged not to punish for contempt for scandalising the judiciary except for the most extreme forms of abuse.

35. Attomey-General v. Guardian Newspapers Lid (No.2) [1990] A.C. 109, [1988] 3 All E.R. 545 (HL).

36. Referred to in Robertson and Nicol, op. cit supra n.18, at p.298.

37. Walker, op. cit supre n.13, at pp.377-378. See also Pannick, op. cit. supre n.6, at pp.115-116, where he points out: "The continued existence of the offence [of scandalising the judiciary under English law], and the memory of successful prosecutions, inhibits journalists, who wrongly suspect that they have a legal obligation to speak respectfully and cautiously when discussing the judiciary. In fact, there is little danger of prosecution nowadays for criticising the judiciary, irrespective of the ferocity of the language used, unless one suggests that the court lacks impartiality."

38. Walker, idem, p.359.

39. A. W. Bradley, "Judges and the Media-The Kilmuir Rules" (1986) P.L. 383, 385.

40. Lord Mackay of Clashfern, The Administration of Justice (1994), pp.25-26.

41. In reply to a parliamentary question on the issue of public statements by judges, the Partiamentary Secretary at the Lord Chancellor's Department (Mr Streeter) reiterated the requirement under the principle of independence of the judiciary "for each judge to decide individually whether to make public statements". He confirmed that a copy of the Lord 
reply to criticism fairly well. The process of liberalising the environment in which UK judges operate has just begun and, while it has to be admitted that it will take some time to reach a stage where criticisms are taken for granted, it is inevitable that the liberalising process is an irreversible one.

The exposure of the judiciary to harsh criticism, often including value judgments and individual opinion, without fear of prosecution has always been the standard practice in the United States. For example, in the case of Bridges v. California $a^{2}$ the US Supreme Court failed to find a constitutional basis for the fines imposed on the petitioners for being in contempt of court when they published their views ${ }^{\text {t3 }}$ on judicial decisions. Justice Black, who wrote on behalf of the majority, opined that the State could curtail freedom of expression only where "the words used are used in such circumstances and are of such a nature as to create a clear and present danger that they will bring about ... substantive evils".4 The judge dismissed the prosecution's argument based on the potential for disrespecting the judiciary, and in the process reiterated what may be identified as the American approach, by pointing out:-s

The assumption that respect for the judiciary can be won by shielding judges from published criticism wrongly appraises the character of American public opinion. For it is a prized American privilege to speak one's mind, al though not always with perfect good taste, on all public institutions. And an enforced silence, however limited, solely in the name of preserving the dignity of the bench, would probably engender resentment, suspicion, and contempt much more than it would enhance respect.

The Court also rejected the attempt to isolate judicial criticism as a special case to

Chancellor's advice on the matter had been sent to every judge and new judges would continue to receive the same advice on appointment. In a follow-up question, Mr Gordon Prentice asked if Streeter did not feel the independence of the judiciary would be compromised in circumstances such as when the Chairman of the Conservative Party, Dr Brian Mawhinney, asked members of the public to write to judges and seek to intimidate them for handing down lenient sentences. Streeter replied: “That was a fairly extraordinary outburst. On appointment in 1987, my right hon. and noble friend the Lord Chancellor relaxed the rules to enable judges to speak out on issues of the day. It is important that experienced and senior judges speak out, express their opinions and take a full part in debates in the House of Lords ... It is important that members of the public make their views known, if they feel that sentences passed in local communities are not appropriate, by going to see or writing to their Members of Parliament. That is what we call democracy": HC Hansard, Vol.289, col.1 (3 Feb. 1997). The author is grateful to Janet Tweedale of the Lord Chancellor's Department for drawing his attention to this statement.

42. 314 U.S. 252 (1941).

43. The most serious of the publications appeared in an editorial of the Los Angeles Times, under the headline "Probation for Gorillas?" in which two members of a labour union who had previously been convicted of assaulting a non-union driver closed with the observation: "Judge A. A. Scott will make a serious mistake if he grants probation to Matthew Shannon and Kennan Holmes."

44. Bridges, supra n.42, at p.261, relying on the previous cases of Gidlow v. New York 268 U.S. 652 (1925) and Schenck v. United States 249 U.S. 47 (1919).

45. Bridges, idem, p.270. He noted further that to regard such publications as causing substantial influence upon the course of justice would be to impute to judges a lack of firmness, wisdom or honour: idem, p.273. Other authors have argued, fairly convincingly too, that the security of tenure enjoyed by judges in democratic society already protects them from any potentially harmful effects of public criticism: see Pannick, op. cit supra n.6, at p.133 and Walker, op. cit supra n.13, at p.381. 
which the constitutional immunity from punishment was inapplicable.* Instead the Court found that "the unqualified prohibitions laid down by the framers [of the constitution] were intended to give to liberty of the press, as to other liberties, the broadest scope that could be countenanced in an orderly society"." A similar approach was adopted by the Court in the later case of Pennekamp v. State of Florida, in which Justice Murphy expressed a strong opinion in support of press freedom and against the offence of contempt of court:

freedom [of the press] covers something more than the right to approve and condone insofar as the judiciary and the judicial process are concerned. It also includes the right to criticise and disparage, even though the terms be vitriolic, scurrilous or erroneous. To talk of a clear and present danger arising out of such criticism is idle unless the criticism makes it impossible in a very real sense for a court to carry on the administration of justice.

It is useful to highlight the US case of Garrison v. State of Louisiana," mainly because the facts of that case bear some similarities to the Prager and Oberschlick case before the European Court of Human Rights. Garrison concerned the conviction of a District Attorney for making uncomplimentary remarks about eight judges of the criminal district of the New Orleans parish. He had told a press conference that he attributed the large backlog of pending criminal cases to the inefficiency, laziness and excessive vacations of the judges. He further accused them of hampering his efforts to enforce the vice laws by refusing to authorise sufficient funding to cover the expenses of undercover investigations. "This", according to him, "raises interesting questions about the racketeer influence on our eight vacation-minded judges." The Supreme Court concluded that the rule which prohibits the punishment of individuals for the criticism of public officials protects the public interest in the flow of information to the people concerning public officials, and to this end anything that might touch on the officials' fitness for office is relevant. According to Justice Brennan, "a candidate [for public office] must surrender to public scrutiny and discussion so much of his private character as affects his fitness for office".so Unlike the European Court of Human Rights in Prager and Oberschlick, the Supreme Court refused to endorse the conviction for contempt of court.

A similar trend of not punishing criticism of the judiciary seems to have emerged in Canadian jurisprudence, especially since the enactment of that country's Charter of Rights and Freedoms. In $R$. v. Kopytoll a lawyer was charged with contempt of court by scandalising the court as a result of comments which he made to a newspaper reporter following the dismissal of a case in which he acted as counsel for the plaintiff. His comments included the following assertions: ${ }^{x}$

46. Bridges, idem, p.263.

47. Idem, p.265.

48. 66 S.C. $1029,1048-1049$ (1946).

49. 379 U.S. 64 (1964).

50. Idem, p.77. It is important to point out that freedom of expression within the context of the US Constitution is not perceived as an absolute right. On this point see Dennis v. United States 341 U.S. 494 (1951).

51. 47 D.L.R. (4th) 213 (1987).

52 Idem, p.219. 
This decision is a mockery of justice. It stints to high hell. It says it is okay to break the law and you are immune so long as someone above you said to do it. Mr Dowson and I have lost faith in the judicial system to render justice. We're wondering what is the point of appealing and continuing this charade of the courts in this country which are wrapped in favour of protecting the police. The courts and the RCMP are sticking so close together you'd think they were put together with Krazy Glue.

The Ontario Court of Appeal allowed his appeal against the conviction for contempt, inter alia, on the ground that the offence of contempt by scandalising the court did not constitute a recognised and permissible limitation upon the guaranteed right of freedom of expression provided by section 2(b) of the Canadian Charter of Rights and Freedoms. ${ }^{3}$ The Court reasoned that the inherent assumption in the offence, which required no proof, that the words spoken by the applicant will bring the court into contempt or lower its authority is arbitrary, unfair and based upon irrational considerations; and in the absence of proof that the words did in fact bring the court into disrepute the conviction should fail the proportionality test required of all permissible limitations under the Charter. ${ }^{34}$ On the wider question of whether judges should receive special protection from criticism in the performance of their duties, Cory JA opined:s

As a result of their importance the courts are bound to be the subject of comment and criticism. Not all will be sweetly reasoned. An unsuccessful litigant may well make comments after a decision is rendered that are not felicitously worded. Some criticism may be well founded, some suggestions for change worth adopting. But the courts are not fragile flowers that will wither in the heat of controversy... They [the courts and judges] need not fear criticism nor need they seek to sustain unnecessary barriers to complaints about their operations or decisions.

In a strong personal statement supporting the decision, Houlden JA expressed his confidence in the strength of the Canadian judiciary and courts "to withstand criticism after a case has been decided no matter how outrageous or scurrilous that criticism may be". He continued: $: 6$

I feel equally confident that the Canadian citizenry are not 80 gullible that they will lose faith and confidence in our judicial system because of such criticism. If the way in which judges and courts conduct their business commands respect, they will receive respect, regardless of any abusive criticism that may be directed towards them ...

I appreciate that by the very nature of their office, judges and courts cannot respond to criticism of what they have done. I do not believe, however, that this is

53. Idem, pp.240-241.

54. Idem, pp. 238-240, citing as authority the Supreme Court decision in R. v. Oakes 26 D.L.R (4th) 200 (1986) especially the judgment of Dickson CJC at p.227.

55. Kopyto, idem, p.227. In an earlier paragraph (idem, p.226) the same judge had applied to judges and courts views which are not too dissimilar from those of the European Court of Human Rights when he asserted: "A democracy cannot exist without the freedom to express new ideas and to put forward opinions about the functioning of public institutions. These opinions may be critical of existing practices in public institutions and of the institutions themsetves. However, change for the better is dependent on constructive criticism. Nor can it be expected that criticism will asways be muted by restraint. Frustration with outmoded practices will often lead to vigorous and unpropitious complaints. Hyperbole and colourful, perhaps even disrespectful language, may be the necessary touchstone to fire the interest and imagination of the public, to the need for reform, and to suggest the manner in which that reform may be achieved."

56. Idem, pp.255-256. 
sufflient justification for putting courts and judges in a different position from other public bodies, such as parliament, provincial legislatures, municipal governments and the police. Accordingly, I would hold that the offence of scandalising the court is inconsiatent with the provisions of the Charter.

The changing attitudes to the criticism of judges and the judiciary has just begun to take shape and a majority of countries-including most of the member States of the Council of Europe- $\rightarrow$ till handle the subject with considerable sensitivity. The changing trend is not by any means an overwhelming one, and in fact the attention of the Court of Human Rights does not seem to have been drawn to this changing practice and the strong reasoning contained in the relevant cases. If and when these cases are considered by the Court one can expect a different approach.

It is undeniable that the changing trend in Canada and the United Kingdom and the standard practice in the United States commend themselves strongly and the more so because they form the standard which provides a more credible human rights protection regime in a modern democratic society. The emerging attitude is more likely than the traditional conservative approach to enhance the fullness of freedom of expression. As one author has strongly argued:57

Criticism of the judiciary is not the dangerous evil feared by those who would protect the courts. The benefits of freedom of expression are as strong in this context as in others. Criticism of judges will not damage the rule of law. It may, by identifying defects in the legal system, promote the cause of justice.

In a democratic society it is prudent to avoid the risk of drowning any group of people, including judges, in veneration and self-satisfaction, only two of the uncommendable vices associated with the absence of criticism."*

\section{Conclusion}

In an environment where all forms of exchange of ideas and opinions are considered beneficial, it should come as no surprise that curbs on criticism by public authorities are considered unacceptable. Because opinion expressed through criticism is usually driven by the desire to question or call public officials to account, it serves the purposes of the democratic society well. The European Court of Human Rights in seeking to uphold the ideals of democratic society has endorsed this idea by interpreting the permissible limitations in paragraph 2 of Article 10 restrictively. The effect of the Court's approach generally, and especially in relation to the criticism of public officials, is to be tolerant of even the most caustic of criticisms. The degree or level of toleration, however, depends on the facts of each case and the Court has sought to consolidate its policy in this regard by distinguishing the effect on the democratic process of criticism of different groups such as governments, politicians and ordinary individuals. Judges, according to the case law of the Court, are not beyond criticism in any society governed by law, although the level of toleration of criticism of them may be lower

58. A similar view has been expressed by idem, p.137. 
than of that of other public officials. In cases involving the criticism of judges, the contracting States are accorded wider margins of appreciation and value judgments will also need to be supported by proof. In an ideal democratic society one would expect that the call on all public officials to account will be without excessive limitation, as has always been the case in the practice relating to the criticism of government policy and politicians. The unique role performed by judges in such a society is, however, perceived as necessitating a different approach to criticism of them because a less than rigorous supervision of that criticism can undermine rather than enhance the democratic process. ${ }^{99}$ This conclusion mirrors the consistent practice in most if not all member States of the Council of Europe. Following the principle that the Court will not impose its own standards of human rights, especially in contexts where there is a sufficiently consistent Europe-wide practice on the specific issue, the Court's conclusions on the criticism of judges are not in conflict with its established case law under Article 10 of the Convention.

It is evident from the discussion thus far about criticising judges that the subject has always been treated with considerable sensitivity. Years, and in some cases centuries, of practice may be necessary to provide the confidence with which to treat the subject differently. The European Court of Human Rights supervises a relatively immature legal regime of no more than half a century and, as a body which is viewed with some understandable degree of remoteness and suspicion, the cautious approach in this matter is advisable. In time, one can expect its confidence to grow and it can then be expected to adopt policies which are more interventionist. The Court cannot, however, afford to ignore the changing trends around the world. Until these trends in themselves become overwhelming in their effect on the thinking of the Court, its present approach to the criticism of judges will remain conservative and imperfect in the eyes of its critics. While it is possible, at the present time at least, to argue that the Court's decisions relating to the criticism of judges are justifiable and satisfactory, this may not be the case in the future. Even with the imperfections of democratic practice in Europe, it is important for the Court to be guided by Blackstone's counsel that:- ${ }^{-0}$

A representative democracy ceases to exist the moment that the public functionaries are by any means absolved from their responsibility to their constituents; and this happens whenever the constituent can be restrained in any manner from speaking. writing or publishing his opinions upon any public measure, or upon the conduct of those who may advise or execute it.

The Court's supervisory role surely extends to ensuring that human rights standards in member States are not diminished in the light of changing circumstances.

Michael K. Addo*

59. See the practice in Canada and the US and to a lesser extent the UK for a contrary approach.

60. Tucker, Blackstone's Commentaries (1803), p.297.

- Faculty of Law, University of Exeter. I am most grateful to Professor Colin Warbrick, Professor John Bridge, Dr Ralph Beddard and Mr David Perrott, who commented on an eartier version of this article. Any errors in it are, however, my own. 